\title{
A 5 Year Retrospective Study of Histopathological Patterns of Ovarian Tumors
}

\author{
Pramila Jain, Reeni Malik and Varsha Rampuri* \\ Dept. of Pathology, Gandhi Medical College, Bhopal, MP, India
}

\begin{abstract}
Background: Ovarian tumors represent about $30 \%$ of all cancers of the female genital system and show a wide spectrum of histological types and clinical behaviour. Ovarian cancer is the leading cause of mortality of female gynaecological cancers and ranks seventh as the most common cancer worldwide. The increasing life expectancy has led to increase in its burden exponentially now even in developing countries but limited knowledge is there about the pattern of ovarian tumours. The present study was done with the aim of studying the histopathological pattern of the ovarian tumors in women of various age groups.

Methods: This was retrospective analysis of all cases of ovarian cancer, and benign ovarian neoplasms received during 5 year period from january 2014 to december 2018 at pathology department of gandhi medical college and hamidia hospital, Bhopal (M.P). Data regarding age and tumor histology were collected from medical records. Routine H/E staining was performed. Immunohistochemistry (IHC) was done in difficult cases.

Result: Of 350 cases $245(45.2 \%)$ were benign, 27 (4.9\%) were borderline / uncertain and 78 (14.4\%) were malignant tumors. For all age groups, benign tumors were more common than malignant ones. Most ovarian tumors were seen between 21-50 years (272, 77.7\%). Surface epithelial tumors were most common $(253,72.2 \%)$ followed by germ cell tumors $(70,12.9 \%)$.
\end{abstract}

Conclusion: The present study has revealed a spectrum of ovarian tumors over a wide range from adolescent to late reproductive to menopausal and late menopausal age grooup. Benign tumors are more common than malignant ones.

Keywords: Surface Epithelial Tumors ; Ovarian Tumors; Germ Cell Tumor.

\section{Introduction}

Ovarian cancer is the seventh most common cancer worldwide. In India, too female cancer cases, especially ovarian cancer figures are escalating. India shows dangerous data of having 3rd highest number of cancer cases among women after China and USA. Infact, India has the 2 nd highest incidence of ovarian cancer globally. ${ }^{[1]}$ Indian cancer registry data project ovary as an important site of cancer in women comprising $8.7 \%$ of cancers in various parts of the country. ${ }^{[2]}$ About $95 \%$ of these tumors have been found to be benign. They are most common during child bearing age of 20 and 45 years whereas malignant tumors are more common in older women between the ages of 45 and 65 years having poor prognosis. ${ }^{[3]}$ The overall 5 -year survival is $45 \%$ primarily because of the late stage at diagnosis of the disease. ${ }^{[4]}$ However, the clinical behavior of this malignancy varies widely, from an excellent prognosis and high likelihood of cure to rapid progression and poor prognosis, most probably reflecting variation in the tumor, biological properties. The survival rate of patients with early stage disease approaches $90 \%$, but most cases are diagnosed late when the symptoms such as abdominal distension caused by ascites or large tumor masses become apparent. ${ }^{[5]}$
The present study was conducted with the aim of studying the histopathological pattern of various ovarian neoplastic lesions and their frequency in different age groups.

\section{Materials and Methods}

This was retrospective analysis of all cases of ovarian cancer, and benign ovarian neoplasms received during 5 year period from january 2014 to december 2018 at pathology department of gandhi medical college and hamidia hospital, Bhopal (M.P). Data regarding age and tumor histology was collected from the archived medical records. Routine H/E staining was performed.

\section{Statistical Analysis}

The data was collected and analyzed using standard statistical chi - square test, $\mathrm{P}<0.05$ statistically significant. Data was entered in Microsoft excel and analysis was done using SPSS version 22.

\section{Result}

A total of 350 different neoplastic lesions of ovaries were studied during 5 year period from january 2014 to december 2018.

Neoplastic tumors included, benign $(245 ; 70 \%)$ borderline / uncertain $(27 ; 7.7 \%)$ and malignant $(78 ; 22.2 \%)$ cases 
(Table. 1) (fig.1). The age range of our patients was from 2 months to 85 years. Surface epithelial tumors were most common $(253,72.2 \%)$ followed by germ cell tumors $(70$, 12.9\%) (Table. 2) (fig.2) . Benign surface epithelial tumors comprised $55.6 \%(195 / 350)$ of all benign tumors includes Serous cystadenoma 145 (41.4\%), Serous cystadenofibroma $03(0.86 \%)$, Mucinous cystadenoma 45 (12.8\%), Benign brenner tumor $02(0.57 \%)$, whereas their malignant counter part formed $13.05 \%$ (46/350) of all malignant tumors which includes Serous cystadenocarcinoma 30 (8.5\%), Mucinous cystadenocarcinoma 12 (3.4\%), Endometroid carcinoma $02(0.57 \%)$, Clear cell carcinoma 01 (0.29\%), Malignant brenner tumor $01(0.29 \%)$. Germ cell tumors includes benign tumors Mature cystic teratoma 45 (12.8\%), Struma ovarii $01 \quad(0.29 \%)$ and malignant tumors include Dysgerminoma 04 (1.1\%), Mature cystic teratoma $03(0.86 \%)$, Yolk sac tumor (endodermal sinus tumor) 06 (1.7\%), Mixed germ cell tumors 10 (2.8\%), Embryonal cell carcinoma $01(0.29 \%)$. Sex cord stromal tumors includes Fibroma 04 (1.1\%), and Granulosa cell tumor 15 (4.2\%) constituting $19(5.4 \%)$ cases of all ovarian tumors. Metastatic tumors $\quad 07(2.01 \%)$ of ovaries includes Carcinoid ovary $01(0.29 \%)$, Krukenberg's tumor 03 $(0.86 \%)$ and $03(0.86 \%)$ cases of Metastasis to ovary.

For all age groups, benign tumors were more common than malignant ones. Most ovarian tumors were seen between 21 - 50 years $(272,77.7 \%)$. (Table. 2) (fig.2). Most commonly seen are surface epithelial tumors and accounted for $253(72.02 \%)$ of all ovarian tumors. Among these, serous cytsadenomas showed wide range of age distribution with youngest case of age 2 month and 4 month and oldest case was 85 year old. Germ cell tumors constituted $19.87 \%$ of all ovarian tumors and seen mostly upto 50 year of age. Seven Metastatic tumors of ovary were found in age group ranging $21-70$ years constituting $1.97 \%$. 01 case of undifferentiated tumor is reported in 55 year age of patient. (Tab no. 3) (fig.3).

Table 1: Distribution of tumors of ovary $(n=350)$.

\begin{tabular}{|c|c|}
\hline Type & Number (\%) \\
\hline Benign & $245(70 \%)$ \\
\hline Borderline /uncertain & $27(7.7 \%)$ \\
\hline Malignant & $78(22.2 \%)$ \\
\hline Total & $350(100) \%$ \\
\hline
\end{tabular}

Table 2: Disribution of ovarian tumors in various age group.

\begin{tabular}{|c|c|c|c|c|}
\hline Age grp (in yrs) & $\begin{array}{c}\text { Benign } \\
(\mathbf{n = 2 4 5})\end{array}$ & $\begin{array}{c}\text { Borderline/uncertain } \\
(\mathbf{n = 2 7 )}\end{array}$ & $\begin{array}{c}\text { Malignant } \\
(\mathbf{n = 7 8})\end{array}$ & $\begin{array}{c}\text { Total } \\
(\mathbf{n = 3 5 0})\end{array}$ \\
\hline $\mathbf{0 - 1 0}$ & $02(0.81 \%)$ & $01(3.7 \%)$ & $02(2.5 \%)$ & $05(1.4 \%)$ \\
\hline $\mathbf{1 1 - 2 0}$ & $17(6.9 \%)$ & $03(11.1 \%)$ & $07(8.9 \%)$ & $27(7.7 \%)$ \\
\hline $\mathbf{2 1 - 3 0}$ & $\mathbf{7 6}(31.0 \%)$ & $05(18.5 \%)$ & $16(20.5 \%)$ & $97(27.7 \%)$ \\
\hline $\mathbf{3 1 - 4 0}$ & $62(25.3 \%)$ & $05(18.5 \%)$ & $22(28.2 \%)$ & $89(25.4 \%)$ \\
\hline $\mathbf{4 1 - 5 0}$ & $62(25.3 \%)$ & $09(33.3 \%)$ & $15(19.2 \%)$ & $86(24.5 \%)$ \\
\hline $\mathbf{5 1 - 6 0}$ & $23(9.3 \%)$ & $02(7.4 \%)$ & $10(12.8 \%)$ & $35(10 \%)$ \\
\hline $\mathbf{6 1 - 7 0}$ & $02(0.81 \%)$ & $02(7.4 \%)$ & $03(3.8 \%)$ & $07(2.0 \%)$ \\
\hline $\mathbf{7 1 - 8 0}$ & $00(0.0 \%)$ & $00(0.0 \%)$ & $03(3.8 \%)$ & $03(0.85 \%)$ \\
\hline $\mathbf{8 1 - 9 0}$ & $01(0.40 \%)$ & $00(0.0 \%)$ & $00(0.0 \%)$ & $01(0.28 \%)$ \\
\hline Total & $\mathbf{2 4 5 ( 1 0 0 \% )}$ & $\mathbf{2 7}(\mathbf{1 0 0} \%)$ & $\mathbf{7 8 ( 1 0 0 \% )}$ & $\mathbf{3 5 0}(\mathbf{1 0 0 \% )}$ \\
\hline
\end{tabular}

Table 3: Frequency of different classes of tumors in different age groups.

\begin{tabular}{|c|c|c|c|c|c|c|}
\hline Age grp in yrs & $\begin{array}{c}\text { Surface } \\
\text { epithelial tumors }\end{array}$ & $\begin{array}{c}\text { Germ cell } \\
\text { tumor }\end{array}$ & $\begin{array}{c}\text { Sex cord } \\
\text { stromal tumor }\end{array}$ & $\begin{array}{c}\text { Metastatic } \\
\text { tumor }\end{array}$ & $\begin{array}{c}\text { Undifferentiated } \\
\text { tumor }\end{array}$ & $\begin{array}{c}\text { Total } \\
0-10\end{array}$ \\
\hline $02(0.57 \%)$ & $02(0.57 \%)$ & $01(0.28 \%)$ & $00(0.0 \%)$ & $00(0.0 \%)$ & $05(1.42 \%)$ \\
\hline $11-20$ & $13(3.7 \%)$ & $13(3.7 \%)$ & $02(0.57 \%)$ & $00(0.0 \%)$ & $00(0.0 \%)$ & $28(8.0 \%)$ \\
\hline $21-30$ & $67(19.1 \%)$ & $25(7.1 \%)$ & $01(0.28 \%)$ & $01(0.28 \%)$ & $00(0.0 \%)$ & $94(26.8 \%)$ \\
\hline $31-40$ & $66(18.8 \%)$ & $18(5.1 \%)$ & $06(1.7 \%)$ & $01(0.28 \%)$ & $00(0.0 \%)$ & $91(26.0 \%)$ \\
\hline
\end{tabular}




\begin{tabular}{|c|c|c|c|c|c|c|}
\hline Age grp in yrs & $\begin{array}{c}\text { Surface } \\
\text { epithelial tumors }\end{array}$ & $\begin{array}{c}\text { Germ cell } \\
\text { tumor }\end{array}$ & $\begin{array}{c}\text { Sex cord } \\
\text { stromal tumor }\end{array}$ & $\begin{array}{c}\text { Metastatic } \\
\text { tumor }\end{array}$ & $\begin{array}{c}\text { Undifferentiated } \\
\text { tumor }\end{array}$ & $\begin{array}{c}\text { Total } \\
\text { tumo }\end{array}$ \\
\hline $41-50$ & $66(18.8 \%)$ & $12(3.4 \%)$ & $07(2.0 \%)$ & $03(0.85 \%)$ & $00(0.0 \%)$ & $88(25.1 \%)$ \\
\hline $51-60$ & $31(8.8 \%)$ & $00(0.0 \%)$ & $01(0.28 \%)$ & $01(0.28 \%)$ & $01(0.28 \%)$ & $34(9.7 \%)$ \\
\hline $61-70$ & $05(1.4 \%)$ & $00(0.0 \%)$ & $01(0.28 \%)$ & $01(0.28 \%)$ & $00(0.0 \%)$ & $07(2.0 \%)$ \\
\hline $71-80$ & $02(0.57 \%)$ & $00(0.0 \%)$ & $00(0.0 \%)$ & $00(0.0 \%)$ & $00(0.0 \%)$ & $02(0.57 \%)$ \\
\hline $81-90$ & $01(0.28 \%)$ & $00(0.0 \%)$ & $00(0.0 \%)$ & $00(0.0 \%)$ & $00(0.0 \%)$ & $01(0.28 \%)$ \\
\hline Total & $\mathbf{2 5 3 ( 7 2 . 0 2 \% )}$ & $\mathbf{7 0 ( 1 9 . 8 7 \% )}$ & $\mathbf{1 9 ( 5 . 3 9 \% )}$ & $\mathbf{0 7 ( 1 . 9 7 \% )}$ & $\mathbf{0 1 ( 0 . 2 8 \% )}$ & $\mathbf{3 5 0 ( 1 0 0 \% )}$ \\
\hline
\end{tabular}

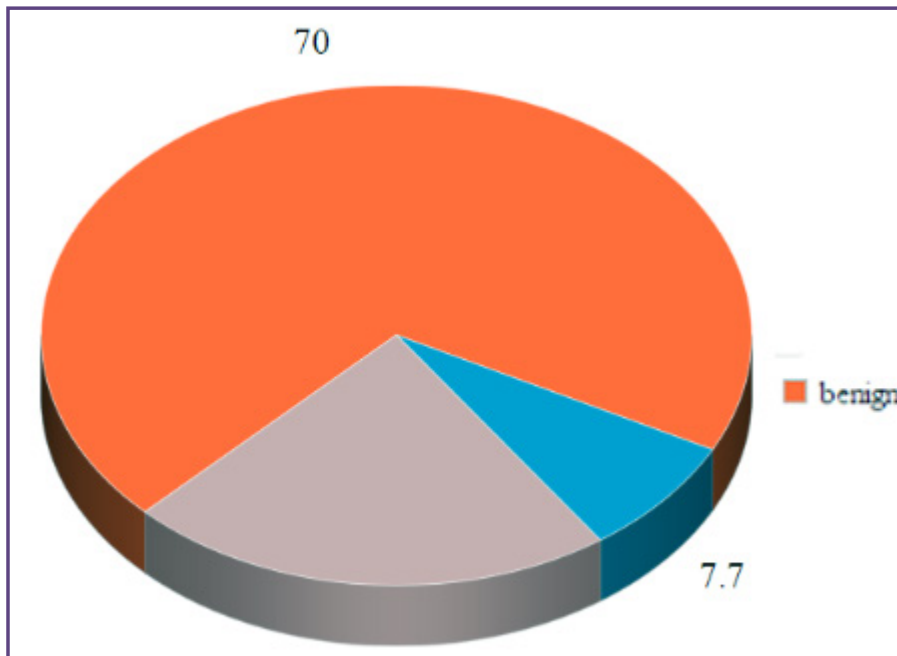

22.2

Fig. 1: Distribution of tumors of ovary $(n=350)$.

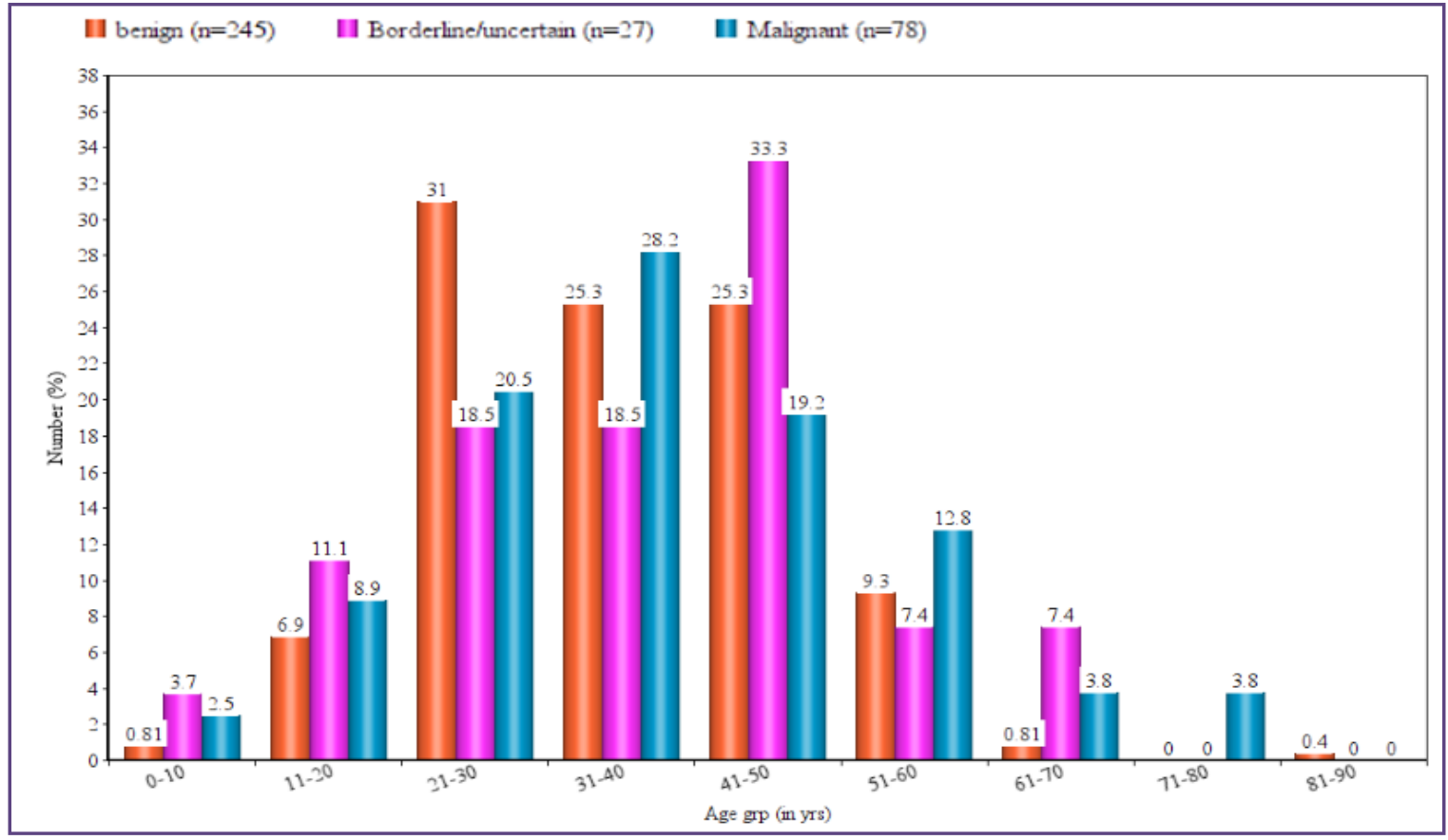

Fig. 2: Disribution of ovarian tumors in various age group 


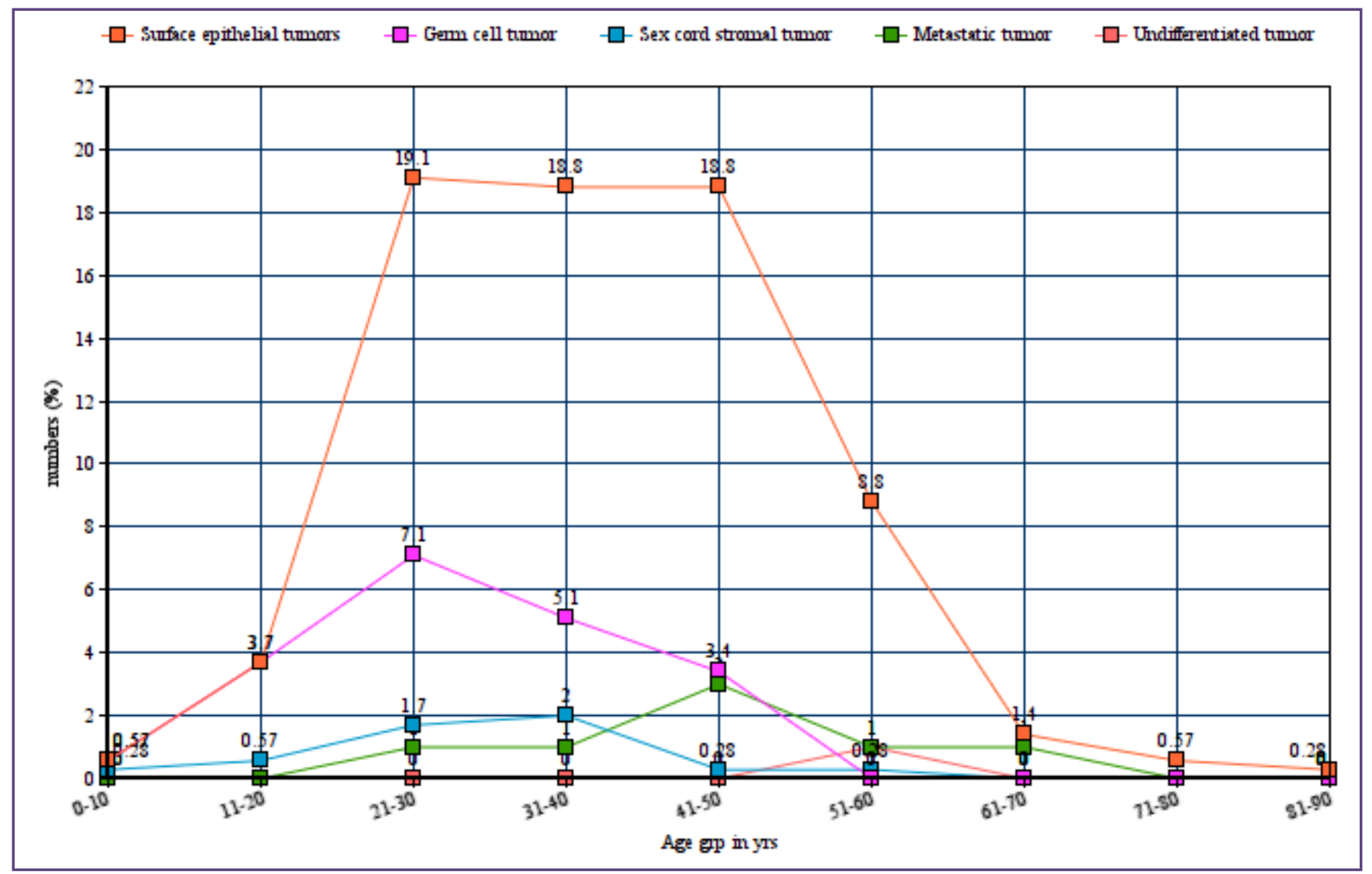

Fig. 3: Frequency of different classes of tumors in different age groups.

\section{Discussion}

Main aspects considered in this study were histopathological types and frequency of different histopathological types of ovarian tumors and tumor like lesions in different age groups. In present study, total 350 cases of ovarian tumors were studied. There were 245 benign (70\%), 27 borderline / uncertain (7.7\%) and 78 malignant $(22.2 \%)$ cases. Similar observations were made by Mankar and Jain ${ }^{[6]}$ and Sanjeev et al. ${ }^{[7]}$

Ovarian tumors are classified according to WHO classification. Among the different histopathological patterns, Benign serous tumors including serous cysts were the commonest benign tumor constituting 39.7\% followed by mature teratoma and mucinous cysts each constituting $12.9 \%$. Studies done by Garg et al., ${ }^{[8]}$ Patil et al., ${ }^{[9]}$ and Modepalli and Venugopal ${ }^{[10]}$ had similar findings. However, in Mankar and Jain ${ }^{[6]}$ mucinous cystadenoma $(32.69 \%)$ was the most common tumor.

In this study germ cell tumors accounted the second most common tumor $19.87 \%$ of all ovarian tumors, similar to the findings of many other studies Sawant A et al., ${ }^{[1]]}$ and Singh S et al. ${ }^{[3]}$
Among 70 cases of germ cell tumors, mature teratoma was the commonest about $12.9 \%$ of all ovarian tumors which is equal to mucinous cystadenoma (12.9\%).

Among malignant tumors, mature cystic teratoma comprising $0.86 \%$, and other $1.1 \%$ of dysgerminoms and $1.6 \%$ of yolk sac tumor was reported as malignant germ cell tumor. This result correlated with studies by Thakkar N,et al., ${ }^{[12]}$ and Prakash A,et al. ${ }^{[13]}$

Sex cord stromal tumors comprises of only $5.4 \%$ of total ovarian tumors, of which $1.1 \%$ of fibroma and $4.2 \%$ of granulosa cell tumor. The incidence was very close to the finding of Thakkar N,et al. ${ }^{[12]}$

Overall ovarian tumors found in the age range of 2 month to 85 years, in our study which is similar to the studies conducted by Garg et al., ${ }^{[8]}$ Mankar and Jain, ${ }^{[6]}$ and Modepalli and Venugopal. ${ }^{[10]}$ However, in Sanjeev et al., ${ }^{[7]}$ the lowest age for ovarian tumors was 2 years. In our study, the lowest age for ovarian tumor was 2 months in one case of simple serous cystadenoma. Maximum age of ovarian tumors was 85 years in our study which corroborated well with the studies done by Patil et al,. ${ }^{[9]}$ And Sanjeev et al. ${ }^{[7]}$ 
Maximum number of cases $27.7 \%$ were in the age range of 21 - 30 years. Similar observations were made by Mankar and Jain. ${ }^{[6]}$

Most of the benign neoplasms were seen in $3^{\text {rd }}$ and $4^{\text {th }}$ decade with mean age of 30.7 years.

Malignant neoplasms were expectedly seen with advancing age peaking in $4^{\text {th }}$ decade of life with mean age of presentation being 37.5 years.

Mankar and Jain. ${ }^{[6]}$ and Garg et al., ${ }^{[8]}$ reported $96 \%$ epithelial tumors in her series. In our study $72.2 \%$ epithelial tumors were diagnosed with 46 cases of malignant epithelial tumors accounting for $13.1 \%$ of all malignant neoplasms. The serous cystadenocarcinoma was the most common tumor in the present study $(30,8.5 \%)$. Also 12 (3.4\%) cases of mucinous cystadenocarcinoma are reported in present study. Similar observations were made in study by olivia et al. ${ }^{[14]}$

\section{Conclusion}

The present study has revealed a spectrum of ovarian tumors over a wide range from adolescent to late reproductive to menopausal and late menopausal age grooup. Benign tumors are more common than malignant ones.

Of 350 cases $245(45.2 \%)$ were benign, 27 (4.9\%) were borderline / uncertain and 78 (14.4\%) were malignant tumors. For all age groups, benign tumors were more common than malignant ones. Most ovarian tumors were seen between $21-50$ years $(272,77.7 \%)$. Surface epithelial tumors were most common $(253,72.2 \%)$ followed by germ cell tumors $(70,12.9 \%)$.

\section{Acknowledgements}

None

\section{Funding}

None

\section{Competing Interests}

None

\section{Reference}

1. Puri S, Chadha V, Pandey A K. Epidemiology of ovarian tumours in Northern India - A tertiary hospital based study. Indian journal of community and family medicine. 2018;4:37-41.

2. Murthy NS, Shalini S, Suman G, Pruthvish S, Mathew A. Changing trends in incidence of ovarian cancer - the Indian scenario. Asian Pac J cancer - prev. 2009;10(6):1025-30.

3. Singh S, Saxena V, Khatri S, et al. Histopathological Evaluation of Ovarian Tumors. Imperial Journal of Interdisciplinary Research, 2016; 2(4): 435-9.

4. Chen VW, Ruiz B, Killeen JL, Coté TR, Wu XC, Correa $\mathrm{CN}$. Pathology and classification of ovarian tumors. Cancer 2003;97 10 Suppl: 2631-42.

5. Jemal A, Siegel R, Ward E, Hao Y, Xu J, Murray T, et al. Cancer statistics, 2008. CA Cancer J Clin 2008;58:7196.

6. Mankar DV, Jain GK. Histopathological profile of ovarian tumours: A twelve year institutional experience. Muller J Med Sci Res 2015;6:107-11.

7. Sanjeev N, Anjali S, Shrikant N, Rahul K. Spectrum of ovarian tumours - A five year study. J Pathol Nepal 2017;7:1180-3.

8. Garg N, Anand AS, Annigeri C. Study of histomorphological spectrum of ovarian tumours. Int $\mathrm{J}$ Med Health Res 2017;3:12-20.

9. Patil RK, Bhandari BJ, Kittur SK, Haravi RM, Aruna S, Jadhav MN. Histomorphological study of ovarian tumours at a tertiary care centre. Ann Pathol Lab Med 2017;4:A638-45.

10. Modepalli N, Venugopal SB. Clinicopathological study of surface epithelial tumours of the ovary: An institutional study. J Clin Diagn Res 2016;10:EC01-4.

11. Sawant A, Mahajan S. Histopathological Study of Ovarian Lesions at a Tertiary Health Care Institute. MVP Journal of Medical Sciences, 2017; 4(1): 26-29.

12. Thakkar N, Shah S. Histopathological Study of Ovarian Lesions. International Journal of Science and Research, 2015; 4(10): 1745-9.

13. Agrawal P, Kulkarni DG, Cahkrabarti PR, et al. Clinicopathological Spectrum of Ovarian Tumors: A 5-Year Experience in a Tertiary Health Care Center. Journal of Basic and Clinical Reproductive Sciences, 2015; 4(2): 90-96.

*Corresponding author:

Dr. Varsha Rampuri, LIG 145 Bhartiniketan, Bhopal (M.P) 462023 India

Phone: +91 9826364657

Email: varsharampuri@gmail.com

Financial or other Competing Interests: None. 